\title{
Neoadjuvant strategies in resectable carcinoma esophagus: a meta-analysis of randomized trials
}

\author{
Tarun Kumar $^{1 *}$, Esha Pai ${ }^{2}$, Rajesh Singh ${ }^{3}$, Neville J. Francis ${ }^{1}$ and Manoj Pandey ${ }^{1}$
}

\begin{abstract}
Background: The survival benefit of neoadjuvant therapy in resectable carcinoma esophagus has been elucidated. We performed a meta-analysis in light of new studies and long-term results of past trials. The search strategy was refined to include only "neoadjuvant" so that any bias by adjuvant treatment is eliminated.

Methods: A detailed search of MEDLINE, Embase, and Cochrane Library was done. Only published randomized English language trials were included. Data were categorized as neoadjuvant concurrent chemoradiation (NACRT), neoadjuvant chemotherapy (NACT), neoadjuvant radiotherapy (NART), and neoadjuvant sequential chemoradiotherapy (SCRT). Meta-analysis was done using odds ratio (OR) and $95 \% \mathrm{Cl}$ using fixed/random effects model. Heterogeneity was tested by chi-square and $P$ test. $Z$ probability calculated significant difference across subgroups. Outcomes assessed were overall survival (OS) and disease-free survival (DFS) at 3 and 5 years, respectively, mortality (30/90 day) and failures (local/systemic).
\end{abstract}

Results: Twenty-five randomized trials involving 5272 patients were included for quantitative analysis. NACRT was evaluated in 12 studies (2676 patients). Superior 3-year OS (OR $=0.68 \mathrm{Cl} 0.52-0.90, p=0.007)$, 3-year DFS (OR $=0.55$ $\mathrm{Cl} 0.45-0.68, p=0.00001)$, and 5-year DFS (OR $=0.59 \mathrm{Cl} 0.47-0.74, p=0.00001)$, with lower failures $(\mathrm{OR}=0.52 \mathrm{Cl}$ $0.37-0.73, p=0.0001)$, were seen in favor of NACRT at the cost of increased perioperative mortality $(\mathrm{OR}=1.79 \mathrm{Cl}$ $1.15-2.80, p=.01)$. However, 5-year OS (OR $=0.78 \mathrm{Cl} 0.60-0.1 .01, p=0.06)$ was not found to be significantly superior. NACT, NART, and SCRT were not found to have any benefit over surgery alone.

Conclusion: This meta-analysis presents strong evidence favoring NACRT over upfront surgery. It also shows no survival advantage of neoadjuvant chemotherapy.

Keywords: Neoadjuvant chemotherapy, Neoadjuvant chemoradiation, Neoadjuvant radiation, Sequential chemoradiation, Carcinoma esophagus, Preoperative chemotherapy, Preoperative chemoradiation

\section{Introduction}

The outcomes of resectable esophageal cancer have remained dismal with an estimated 5-year survival of 50$55 \%$ [1]. To overcome this, a number of studies were carried out to evaluate the impact of the addition of

\footnotetext{
* Correspondence: batra_tarun@hotmail.com

The authors Esha Pai and Rajesh Singh share the second authorship

${ }^{1}$ Department of Surgical Oncology, Banaras Hindu University, Varanasi 221005, India

Full list of author information is available at the end of the article
}

chemotherapy and radiotherapy to surgery [2-27]. These trials evaluated the effect of adjuvant and neoadjuvant treatment but with equivocal results. Adjuvant therapy merits an accurate pathological staging of disease but also risks non-completion of systemic therapy in the face of surgical morbidity. Meanwhile, neoadjuvant treatment has its advantages in the form of undisturbed tumor bed with better oxygenation and optimal patient performance in a

(c) The Author(s). 2020 Open Access This article is licensed under a Creative Commons Attribution 4.0 International License, which permits use, sharing, adaptation, distribution and reproduction in any medium or format, as long as you give appropriate credit to the original author(s) and the source, provide a link to the Creative Commons licence, and indicate if changes were made. The images or other third party material in this article are included in the article's Creative Commons licence, unless indicated otherwise in a credit line to the material. If material is not included in the article's Creative Commons licence and your intended use is not permitted by statutory regulation or exceeds the permitted use, you will need to obtain permission directly from the copyright holder. To view a copy of this licence, visit http://creativecommons.org/licenses/by/4.0/ The Creative Commons Public Domain Dedication waiver (http://creativecommons.org/publicdomain/zero/1.0/) applies to the data made available in this article, unless otherwise stated in a credit line to the data. 
treatment-naive setting but at the cost of increased perioperative morbidity and mortality.

Neoadjuvant treatment of esophageal cancer, in the recent past, has drawn attention with many newer trials having been published $[11,16]$. With inconclusive evidence [28-30] comparing neoadjuvant chemoradiotherapy (NACRT) to neoadjuvant chemotherapy (NACT) and meta-analyses [31] not showing convincing results favoring either modality of treatment, NACRT and NACT, continue to be practiced in different parts of the world as per institutional protocol and individual preferences.

We, in this meta-analysis, have compared NACRT and NACT separately to upfront surgery with a more refined and stringent search strategy to elucidate any possible effect that either may have. We also included the newest randomized trial [11] and long-term results of previously published trial [16]. Prior meta-analyses [31-33] on this subject have considered studies where adjuvant treatment was given (chemotherapy or radiotherapy) after surgery following neoadjuvant treatment, making it difficult to interpret the impact of purely neoadjuvant treatment. Hence, we included randomized control trials where only neoadjuvant treatment strategies were used without any peri- or post-operative treatment, so that any bias introduced by adjuvant treatment may be eliminated. This meta-analysis uses only published randomized controlled trials. Other unpublished abstracts presented in meetings and prospective cohort studies have not been included.

\section{Methods}

We included all the published randomized controlled trials of neoadjuvant treatment for esophagus or esophagogastric cancer (EGC) (Siewert 1 and 2) followed by surgery versus upfront surgery for resectable disease. A detailed literature search was carried out in MEDLINE (PubMed), Embase, and Cochrane databases. We used the following search strings:

(("esophagus"[All Fields] OR "esophagus"[MeSH Terms] OR "esophagus"[All Fields]) OR ("esophagus"[All Fields] OR "esophagus"[MeSH Terms] OR "esophagus"[All Fields])) AND (("neoadjuvant therapy"[MeSH Terms] OR ("neoadjuvant"[All Fields] AND "therapy"[All Fields]) OR "neoadjuvant therapy"[All Fields] OR "neoadjuvant"[All Fields]) OR preoperative[All Fields]) AND (("drug therapy"[Subheading] OR ("drug"[All Fields] AND "therapy"[All Fields]) OR "drug therapy"[All Fields] OR "chemotherapy"[All Fields] OR "drug therapy"[MeSH Terms] OR ("drug"[All Fields] AND "therapy"[All Fields]) OR "chemother apy"[All Fields]) OR ("radiotherapy"[Subheading] OR "radiotherapy"[All Fields] OR "radiotherapy"[MeSH Terms]) OR ("chemoradiotherapy"[MeSH Terms] OR "chemoradiotherapy"[All Fields])) AND Clinical Trial[ptyp] AND
English[lang]. The last search was done on August 28, 2019, on PubMed.

Out of 232 studies found from the above search, 16 were shortlisted after abstract reviews. An additional 33 studies were identified from previous meta-analyses and 3 were found during a manual search of back-references. In all, after the elimination of duplicates and exclusions, 25 studies were considered for the final analysis (Fig. 1, Table 1).

\section{Inclusion and exclusion criteria}

All randomized trials that compared upfront surgery with neoadjuvant chemotherapy (NACT), radiotherapy (NART), concurrent chemoradiation (NACRT), or sequential chemoradiation (SCRT) followed by surgery were included. Operability was considered based on preoperative evaluation techniques of respective studies based on tumor size, extent, infiltration into surrounding tissues, lymph node, or distant metastases as evaluated by the authors of individual trials, respectively.

Exclusion criteria entailed perioperative chemotherapy, where adjuvant treatment (chemotherapy or radiation) was given, mixed tumor subsites (stomach and esophagus) where subset analyses of esophageal and gastric cancers were not done separately, and unpublished abstracts presented in meetings and in non-English language manuscripts.

\section{Data extraction}

Two authors individually scanned all abstracts and shortlisted studies meeting the above inclusion criteria. Data from each of these shortlisted studies was collected on a pre-set proforma. Any discrepancies in the inclusion were settled after discussion with a third member. The quality of each study was evaluated using Jadad's score [36] (Table 1). Data were categorized into four groups: neoadjuvant concurrent chemoradiation, neoadjuvant chemotherapy, neoadjuvant radiotherapy, and neoadjuvant sequential chemoradiation.

For final analyses, 6 endpoint variables were compared. The primary endpoints were overall survival (OS) and disease-free survival (DFS) at 3 and 5 years. Secondary endpoints were 30 - or 90-day mortality (as given in the studies) and failures (local and systemic). The OS is defined as the time from date of recruitment to death, and DFS was described as time from recruitment to recurrence or metastasis, as described in studies. Publication bias was measured using a funnel plot [37].

\section{Statistical analysis}

Treatment failure rates, mortality rates, 3- and 5-year overall and disease-free survival rates were extracted and entered in the REVMAN 5.2 software. For dichotomous variables, odds ratios with their $95 \%$ confidence intervals 


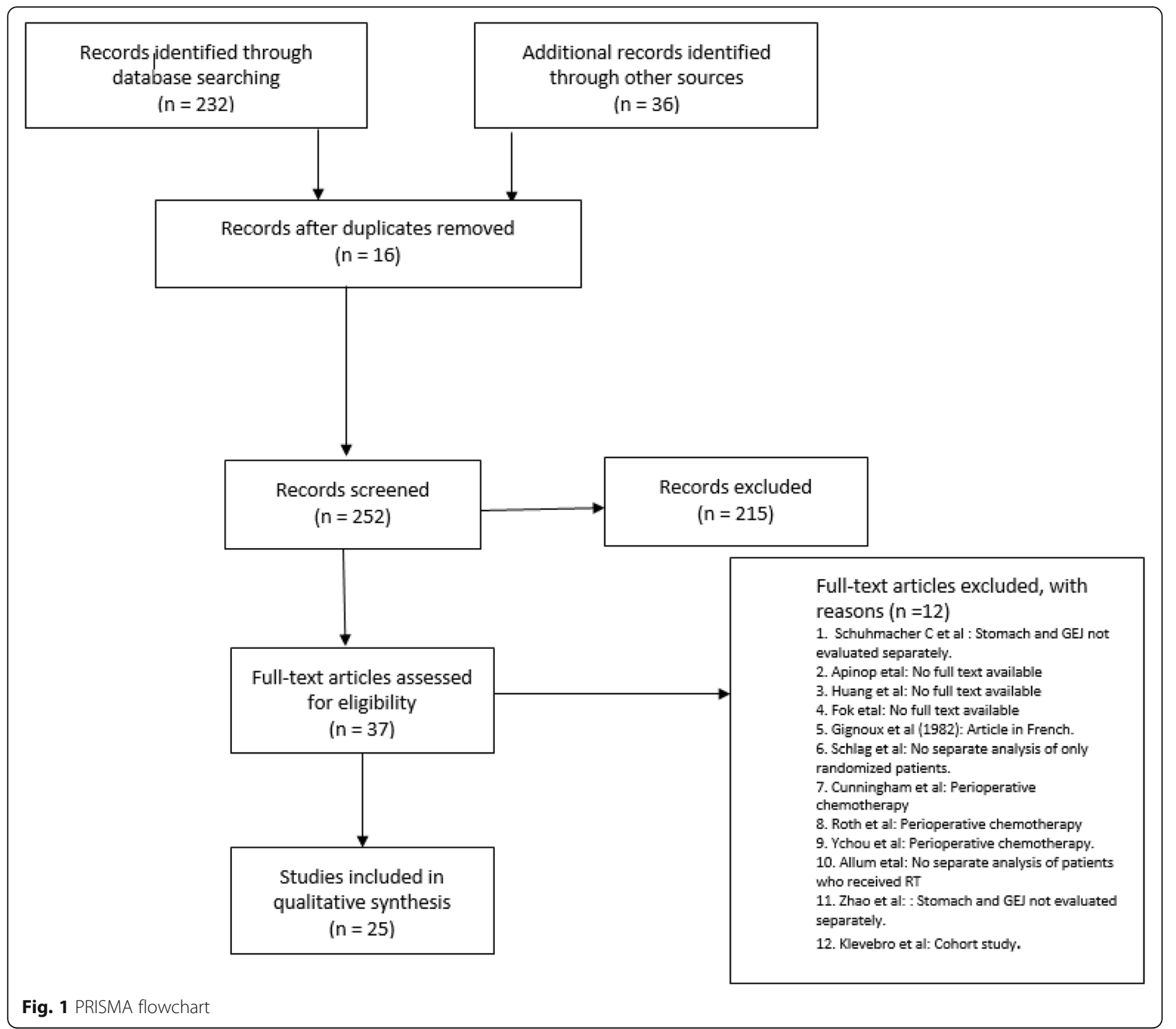

were calculated with Mantel-Haenszel methods using fixed (if no heterogeneity) or random-effects model $\left(I^{2}>\right.$ 40\%) [38]. Heterogeneity was tested using chi-square and $I^{2}$ tests, and significance was tested using the $Z$ test.

The manuscript has been presented in accordance with the Preferred Reporting Items for Systematic Reviews and Meta-Analyses (PRISMA) guidelines [39], and the checklist of the same has been provided in the supplementary material (Supplementary file 15).

\section{Results}

Twenty-five randomized trials involving 5272 patients were included for quantitative analysis. All variables were not available in all studies, hence only those studies with particular variables were used for individual meta-analysis.

\section{Neoadjuvant chemoradiotherapy (NACRT)}

NACRT was the most extensively studied neoadjuvant strategy with a total of 12 trials and 2676 patients. The results showed distinct advantage of NACRT over upfront surgery with lower failures (local and systemic) $(\mathrm{OR}=0.52 \mathrm{CI} 0.37-0.73, p=0.0001)$ (Fig. 2), superior DFS at 3 years $(\mathrm{OR}=0.55 \mathrm{CI} 0.45-0.68, p=0.00001)$ (Supplementary file 1), superior DFS at 5 years $(\mathrm{OR}=$ 0.59 CI $0.47-0.74, p=0.00001$ ) (Supplementary file 2), and superior $\mathrm{OS}$ at 3 years $(\mathrm{OR}=0.68 \mathrm{CI} 0.52-0.90, p=$ 0.007 ) (Fig. 3). There was a trend towards survival benefit seen in $\mathrm{OS}$ at 5 years $(\mathrm{OR}=0.78 \mathrm{CI} 0.60-0.1 .01, p=$ 0.06) (Fig. 4); however, it did not reach significance. Significantly more perioperative mortality was seen (30 or 90 days) in the NACRT group (OR $=1.79 \mathrm{CI} 1.15-2.80$, $p=.01$ ) (Fig. 5) compared to the surgery-alone arm. 
Table 1 The quality of each study evaluated using Jadad's score

\begin{tabular}{|c|c|c|c|c|c|c|c|c|c|}
\hline \multirow{2}{*}{\multicolumn{2}{|c|}{ Study and reference no. }} & \multirow[t]{2}{*}{ Arms } & \multirow{2}{*}{$\begin{array}{l}\text { Sample } \\
\text { size }\end{array}$} & \multirow[t]{2}{*}{ Treatment schedule } & \multirow[t]{2}{*}{ No. of cycles } & \multicolumn{4}{|c|}{ Jadad's score } \\
\hline & & & & & & $R$ & $B$ & $D$ & $\overline{\text { Total }}$ \\
\hline 1. & Ancona et al. (2001) [3] & NACT vs Sx & 96 & $\begin{array}{l}\text { Cisplatin } 100 \mathrm{mg} / \mathrm{m}^{2} \text { on day } 1 \\
\text { 5-Fluorouracil } 1000 \mathrm{mg} / \mathrm{m}^{2} \text { days } 1 \text { to } 5\end{array}$ & 02 (21-day cycle) & $\begin{array}{l}1+ \\
1\end{array}$ & 0 & 1 & 3 \\
\hline 2. & Kelson et al. (1998) [4] & NACT vs Sx & 440 & $\begin{array}{l}\text { Cisplatin } 100 \mathrm{mg} / \mathrm{m}^{2} \text { on day } 1 \\
5 \text {-Fluorouracil } 1000 \mathrm{mg} / \mathrm{m}^{2} \text { days } 1 \text { to } 5\end{array}$ & 03 (29-day cycle) & $\begin{array}{l}1+ \\
1\end{array}$ & 0 & 1 & 3 \\
\hline 3. & Law et al. (1997) [5] & NACT vs Sx & 147 & $\begin{array}{l}\text { Cisplatin } 100 \mathrm{mg} / \mathrm{m}^{2} \text { on day } 1 \\
5 \text {-Fluorouracil } 1000 \mathrm{mg} / \mathrm{m}^{2} \text { days } 1 \text { to } 5\end{array}$ & $\begin{array}{l}02 \text { (22-26-day } \\
\text { cycle) }\end{array}$ & 1 & 0 & 1 & 2 \\
\hline 4. & MRC (2002) [9] & NACT vs Sx & 802 & $\begin{array}{l}\text { Cisplatin } 100 \mathrm{mg} / \mathrm{m}^{2} \text { on day } 1 \\
\text { 5-Fluorouracil } 1000 \mathrm{mg} / \mathrm{m}^{2} \text { days } 1 \text { to } 4\end{array}$ & 02 (21-day cycle) & $\begin{array}{l}1+ \\
1\end{array}$ & 0 & 1 & 3 \\
\hline 5. & Maipang et al. (1994) [7] & NACT vs Sx & 46 & $\begin{array}{l}\text { Cisplatin } 100 \mathrm{mg} / \mathrm{m}^{2} \text { on day } 1 \\
\text { Vinblastine, } 3 \mathrm{mg} / \mathrm{m}^{2} \text { on days } 1,8,15 \text {, and } 22 \\
\text { Bleomycin } 10 \mathrm{mg} / \mathrm{m}^{2} \text {, on day } 3 \text { followed by a } \\
\text { 4-day infusion of } 10 \mathrm{mg} / \mathrm{m}^{2} / \text { day }\end{array}$ & 02 (29-day cycle) & 1 & 0 & 1 & 2 \\
\hline 6. & $\begin{array}{l}\text { Boonstra et al. (2011) } \\
\text { [23] }\end{array}$ & NACT vs SX & 169 & $\begin{array}{l}\text { Cisplatin } 100 \mathrm{mg} / \mathrm{m}^{2} \text { on day } 1 \text {, Etoposide } \\
100 \mathrm{mg} / \mathrm{m}^{2} \text { intravenously on days } 1 \text { and } 2, \\
\text { followed by Etoposide } 200 \mathrm{mg} / \mathrm{m}^{2} \text { orally } \\
\text { on days } 3-5 \text {. }\end{array}$ & 03 (28-day cycle) & 1 & 0 & 1 & 2 \\
\hline 7. & Baba et al. (2000) [22] & NACT vs Sx & 21 & $\begin{array}{l}\text { Cisplatin } 70 \mathrm{mg} / \mathrm{m}^{2} \text { on day } 1 \\
\text { 5-Fluorouracil } 700 \mathrm{mg} / \mathrm{m}^{2} \text { days } 1 \text { to } 5 \\
\text { Leucovorin } 20 \mathrm{mg} / \mathrm{m}^{2} \text { days } 1 \text { to } 5\end{array}$ & $\begin{array}{l}02 \text { (28-32 day } \\
\text { cycle) }\end{array}$ & $\begin{array}{l}1+ \\
1\end{array}$ & 0 & 1 & 3 \\
\hline 8. & Bosset et al. (1997) [24] & NACRT vs Sx & 282 & $\begin{array}{l}\text { Cisplatin } 80 \mathrm{mg} / \mathrm{m}^{2} \text { on days } 0-2 \\
\text { Total radiation dose: } 37.5 \mathrm{~Gy}\end{array}$ & 02 & 1 & 0 & 1 & 2 \\
\hline 9. & Urba et al. (2001) [18] & NACRT vs Sx & 100 & $\begin{array}{l}\text { Cisplatin } 20 \mathrm{mg} / \mathrm{m}^{2} \text { days } 1-5 \\
\text { 5-Fluorouracil } 300 \mathrm{mg} / \mathrm{m}^{2} \text { days } 1-21 \\
\text { Vinblastine } 1 \mathrm{mg} / \mathrm{m}^{2} \text { days } 1-4 \\
\text { Total radiation dose: } 45 \mathrm{~Gy}\end{array}$ & 02 & 1 & 0 & 1 & 2 \\
\hline 10. & NEOCTREC (2018) [11] & NACRT vs Sx & 451 & $\begin{array}{l}\text { Cisplatin } 75 \mathrm{mg} / \mathrm{m}^{2} \text { day } 1 \text { or Cisplatin } \\
25 \mathrm{mg} / \mathrm{m}^{2} \text { days } 1 \text { to } 4 \\
\text { Vinorelbine } 25 \mathrm{mg} / \mathrm{m}^{2} \text { days } 1 \text { and } 8 \\
\text { Total radiation dose: } 40 \mathrm{~Gy}\end{array}$ & 02 & $\begin{array}{l}1+ \\
1\end{array}$ & 0 & 1 & \\
\hline 11. & Lee et al. (2004) [6] & NACRT vs Sx & 101 & $\begin{array}{l}\text { Cisplatin } 60 \mathrm{mg} / \mathrm{m}^{2} \text { day } 1 \\
\text { 5-Fluorouracil } 1000 \mathrm{mg} / \mathrm{m}^{2} \text { days } 2 \text { to } 5 \\
\text { Total radiation dose: } 45.6 \mathrm{~Gy}\end{array}$ & 02 & $\begin{array}{l}1+ \\
1\end{array}$ & 0 & 1 & 3 \\
\hline 12. & Shapiro et al. (2015) [16] & NACRT vs Sx & 366 & $\begin{array}{l}\text { Carboplatin AUC } 2 \mathrm{mg} / \mathrm{ml} / \mathrm{min} \text { day } 1 \\
\text { Paclitaxel } 50 \mathrm{mg} / \mathrm{m}^{2} \text { day } 1 \\
\text { Total radiation dose: } 41.4 \mathrm{~Gy}\end{array}$ & 05 & $\begin{array}{l}1+ \\
1\end{array}$ & 0 & 1 & 3 \\
\hline 13. & $\begin{array}{l}\text { Natsugoe et al. (2006) } \\
{[10]}\end{array}$ & NACRT vs Sx & 45 & $\begin{array}{l}\text { Cisplatin } 7 \mathrm{mg} \\
\text { 5-Fluorouracil } 350 \mathrm{mg} \\
\text { Total radiation dose: } 40 \mathrm{~Gy}\end{array}$ & 20 & $\begin{array}{l}1+ \\
1\end{array}$ & 0 & 1 & 3 \\
\hline 14. & Tepper et al. (2008) [17] & NACRT vs Sx & 56 & $\begin{array}{l}\text { Cisplatin } 100 \mathrm{mg} / \mathrm{m}^{2} \text { day } 1 \\
\text { 5-Fluorouracil } 1000 \mathrm{mg} / \mathrm{m}^{2} \text { days } 1-4 \\
\text { Total radiation dose: } 50.4 \mathrm{~Gy}\end{array}$ & 02 & 1 & 0 & 1 & 2 \\
\hline 15. & Mariette et al. (2014) [8] & NACRT vs Sx & 195 & $\begin{array}{l}\text { Cisplatin } 75 \mathrm{mg} / \mathrm{m}^{2} \text { day } 1 \\
\text { 5-Fluorouracil } 800 \mathrm{mg} / \mathrm{m}^{2} \text { days } 1-4 \\
\text { Total radiation dose: } 45 \mathrm{~Gy}\end{array}$ & 02 & $\begin{array}{l}1+ \\
1\end{array}$ & 0 & 1 & 3 \\
\hline 16. & Lv et al. (2010) [34] & NACRT vs Sx & 238 & $\begin{array}{l}\text { Cisplatin } 20 \mathrm{mg} / \mathrm{m}^{2} \text { days } 1-3 \\
\text { Paclitaxel } 135 \mathrm{mg} / \mathrm{m}^{2} \text { day } 1 \\
\text { Total radiation dose: } 40 \mathrm{~Gy}\end{array}$ & 02 & $\begin{array}{l}1+ \\
1\end{array}$ & 0 & 0 & 2 \\
\hline 17. & Walsh et al. (1996) [19] & NACRT vs Sx & 113 & $\begin{array}{l}\text { Cisplatin75 mg/m² day } 7 \\
\text { 5-Fluorouracil } 15 \mathrm{mg} / \mathrm{kg} / \text { day days } 1-5 \\
\text { Total radiation dose: } 40 \mathrm{~Gy}\end{array}$ & 02 & 1 & 0 & 1 & 2 \\
\hline 18. & $\begin{array}{l}\text { Burmeister et al. (2005) } \\
\text { [25] }\end{array}$ & NACRT vs Sx & 256 & $\begin{array}{l}\text { Cisplatin } 80 \mathrm{mg} / \mathrm{m}^{2} \\
\text { 5-Fluorouracil } 800 \mathrm{mg} / \mathrm{m}^{2} \text { days 1-4 } \\
\text { Total radiation dose: } 35 \mathrm{~Gy}\end{array}$ & 01 & $\begin{array}{l}1+ \\
1\end{array}$ & 0 & 1 & 3 \\
\hline 19. & Le Prise et al. (1994) [13] & SCRT vs SX & 104 & Cisplatin $100 \mathrm{mg} / \mathrm{m}^{2}$ day 1 & 02 & 0 & 0 & 1 & 1 \\
\hline
\end{tabular}


Table 1 The quality of each study evaluated using Jadad's score (Continued)

\begin{tabular}{|c|c|c|c|c|c|c|c|c|c|}
\hline & \multirow[t]{2}{*}{ Study and reference no. } & \multirow[t]{2}{*}{ Arms } & \multirow{2}{*}{$\begin{array}{l}\text { Sample } \\
\text { size }\end{array}$} & \multirow[t]{2}{*}{ Treatment schedule } & \multirow[t]{2}{*}{ No. of cycles } & \multicolumn{4}{|c|}{ Jadad's score } \\
\hline & & & & & & $R$ & $B$ & $D$ & Total \\
\hline 20. & Wang et al. (1998) [20] & NART vs Sx & 206 & Total radiation dose: $40 \mathrm{~Gy}$ & & 1 & 0 & 0 & 1 \\
\hline 21. & Lanouis et al. (1981) [35] & $\begin{array}{l}\text { NART } \\
\text { VS SX }\end{array}$ & 124 & Total radiation dose: $40 \mathrm{~Gy}$ & & 1 & 0 & 1 & 2 \\
\hline 22. & $\begin{array}{l}\text { Gignoux et al. (1987) } \\
\text { [27] }\end{array}$ & $\begin{array}{l}\text { NART } \\
\text { VS Sx }\end{array}$ & 126 & Total radiation dose: $33 \mathrm{~Gy}$ & & 1 & 0 & 0 & 1 \\
\hline 23. & Arnott et al. (1992) [21] & $\begin{array}{l}\text { NART } \\
\text { vs Sx }\end{array}$ & 129 & Total radiation dose: $20 \mathrm{~Gy}$ & & $\begin{array}{l}1+ \\
1\end{array}$ & 0 & 1 & 3 \\
\hline 24. & $\begin{array}{l}\text { Nygaard et al. (1992) } \\
\text { [12] }\end{array}$ & $\begin{array}{l}\text { NACT } \\
\text { vs SCRT vs NART vs } \\
\text { Sx }\end{array}$ & 186 & $\begin{array}{l}\text { Cisplatin } 20 \mathrm{mg} / \mathrm{m}^{2} \text { days } 1 \text { to } 5 \\
\text { Bleomycin } 50 \mathrm{mg} / \mathrm{m}^{2} \text { days } 1-5 \\
\text { Total radiation dose: } 35\end{array}$ & $\begin{array}{l}02 \text { (15-23-day } \\
\text { cycle) }\end{array}$ & 1 & 0 & 1 & 2 \\
\hline 25. & Cao et al. (2009) [26] & $\begin{array}{l}\text { NACT } \\
\text { vs NACRT vs NART vs } \\
\text { Sx }\end{array}$ & 473 & $\begin{array}{l}\text { Cisplatin } 20 \mathrm{mg} / \mathrm{m}^{2} \text { days } 1-5 \\
5 \text {-Fluorouracil } 500 \mathrm{mg} / \mathrm{m}^{2} \text { days } 1-5 \\
\text { Mitomycin } 10 \mathrm{mg} / \mathrm{m}[2] / \text { day, day } 1 \\
\text { Total radiation dose: } 40 \mathrm{~Gy}\end{array}$ & NA & 1 & 0 & 0 & 1 \\
\hline
\end{tabular}

NACT neoadjuvant chemotherapy, NACRT neoadjuvant concurrent chemoradiation, NART neoadjuvant chemoradiation, SCRT neoadjuvant sequential chemoradiation, $S x$ surgery, $R$ randomization, $B$ blinding, $D$ description

\section{Neoadjuvant chemotherapy (NACT)}

NACT was evaluated in nine studies with a total of 2380 patients. NACT followed by surgery failed to show any significant benefit over upfront surgery alone for any of the variables studied. There was a trend towards superior 3-year OS $(\mathrm{OR}=0.85,95 \% \mathrm{CI} 0.68-1.06, p=0.14)$ (Supplementary file 6) and 5-year OS (OR $=0.7295 \% \mathrm{CI}$ $0.49-1.07, p=0.11$ ) (Supplementary file 8) in favor of NACT, but it failed to reach statistical significance.

\section{Neoadjuvant radiotherapy (NART)}

NART was investigated in 6 trials with a total of 1244 patients. Treatment-related mortality for neoadjuvant radiotherapy was studied in 3 trials with 439 participants and showed no significant difference (Supplementary file 9). The 3-year OS was reported in 3 trials, with a total of 865 patients whereas 5-year OS was reported in 4 trials with 582 patients. There was a distinct $42 \%$ benefit in the 3 -year OS (OR $=0.58$ 95\% CI 0.39-0.86, $p=0.007$ ) (Supplementary file 11) in favor of NART followed by surgery which was inapparent in the 5-year OS (OR $=1.0195 \%$ CI 0.65$1.59, p=0.96$ ) (Supplementary file 12).

\section{Sequential chemoradiation (SCRT)}

There were 2 studies with 290 patients which investigated SCRT. Only two variables, i.e., perioperative mortality and 3-year OS were recorded in these studies (supplementary material $13 \& 14$ ). The results of neither of the two variables reached clinical significance.

\section{Discussion}

This meta-analysis demonstrates the benefit of NACRT across all variables evaluated, except 30/90-day mortality. NACRT showed a significant overall survival benefit of $32 \%$ at 3 years. This benefit diminished at 5 years (22\%) as it only showed a trend towards statistical significance. However, these figures need to be interpreted with caution as the studies had heterogeneity amongst them. Further, these promising results were at the cost of a $79 \%$ increase in perioperative mortality in the NACRT group compared to surgery alone. The metaanalysis also showed 48\% lower recurrences (systemic and locoregional) in the NACRT arm. In comparison, Chan et al. [33] showed an absolute survival benefit of $25 \%$ with a $46 \%$ increase in perioperative mortality with

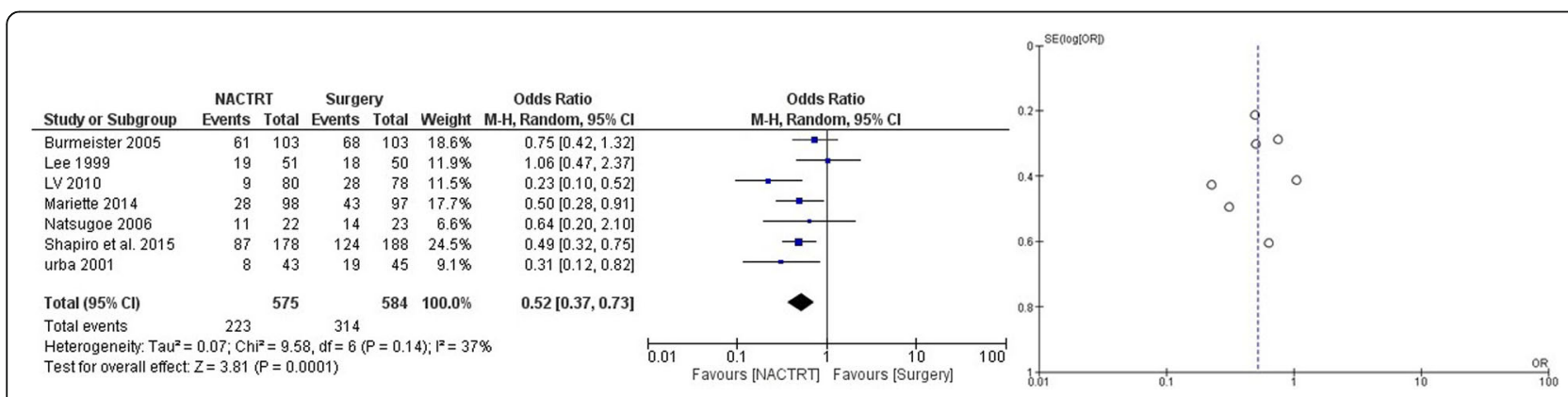

Fig. 2 Forest and funnel plot comparing failures in NACRT and upfront surgery arms 


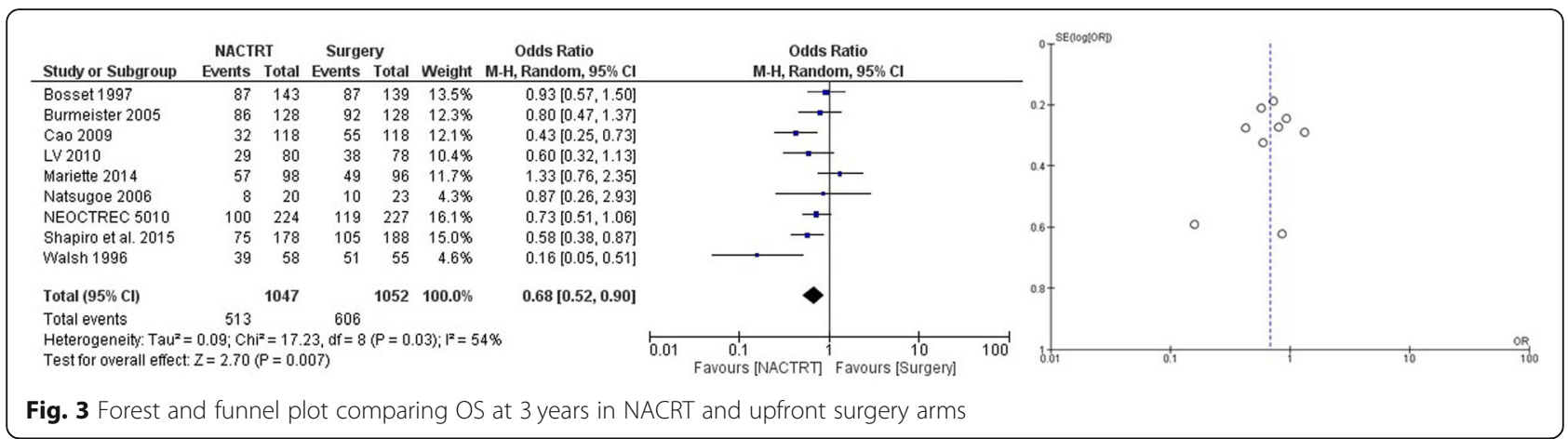

NACRT whereas Sjoquist and colleagues [31] showed an absolute benefit of $8.7 \%$ in all-cause mortality at 2 years.

The 5-year OS did show a strong trend towards survival benefit but did not reach significance and can be interpreted in three disparate ways. First, we hypothesize lack of sufficient data, i.e., if there was probably one more trial or more patients in any of the trials wherein survival in the NACRT group was higher, and this figure would also be significant like all the other variables. Second, NACRT did not fare better than upfront surgery as some of the long-term failures of surgery alone may have been salvaged with radiation or chemotherapy so that the 5-year OS was similar to that of NACRT; however, this information on the use of salvage therapy is missing in most studies. Third, there is also a possibility of increased non-cancer-related deaths in the long term in the NACRT group. The latter was seen in the NeoRes trial by Klevebro et al. [30] which demonstrated $46 \%$ of NACRT patients died of non-cancer-related deaths at 1 year. With the data available to us, it is not possible to comment on this phenomenon, and it should be seen as an absence of evidence and not as evidence of absence.

Another point of contention is whether the perioperative mortality in these trials has been included as events in the calculation of OS for the NACRT arm. None of the trials have explicitly described this pertinent aspect in their articles, and it is not clear if they have used an intention-to-treat analysis, hence the exact statistical effect of perioperative mortality on overall survival cannot be ascertained.

All these results are not surprising as the comparison is being made between two unbalanced arms, i.e., multimodality treatment (radiotherapy, chemotherapy, surgery) versus single modality (surgery alone). It is now established that surgery alone is insufficient for the treatment of resectable esophageal cancer and the addition of chemoradiotherapy is essential to achieve better results. However, the timing of the chemoradiotherapy (preoperative or postoperative) needs to be investigated as there may be a reduction in peri-operative mortality if chemoradiotherapy is given in the adjuvant setting, instead of as neoadjuvant. The QUINTETT study by Malthaner et al. [40] presented as an abstract compared health-related quality of life (HRQL) of neoadjuvant and adjuvant chemoradiation for resectable esophageal cancer. They showed no significant difference in HRQL scores but reported significantly more chemotherapy-related adverse events in the neoadjuvant arm. Surgery-related adverse events were also significantly more in the neoadjuvant arm. Miccio et al. [41] analyzed the surveillance, epidemiology, and end result (SEER) registry database from 2001-2011 of Siewert's type II GEJ cancers. Of 1497 patients they analyzed, 746 received adjuvant RT and 751 received neoadjuvant RT. They concluded that adjuvant RT is associated with a significantly lower death risk hazard ratio $(0.8495 \% \mathrm{CI}$

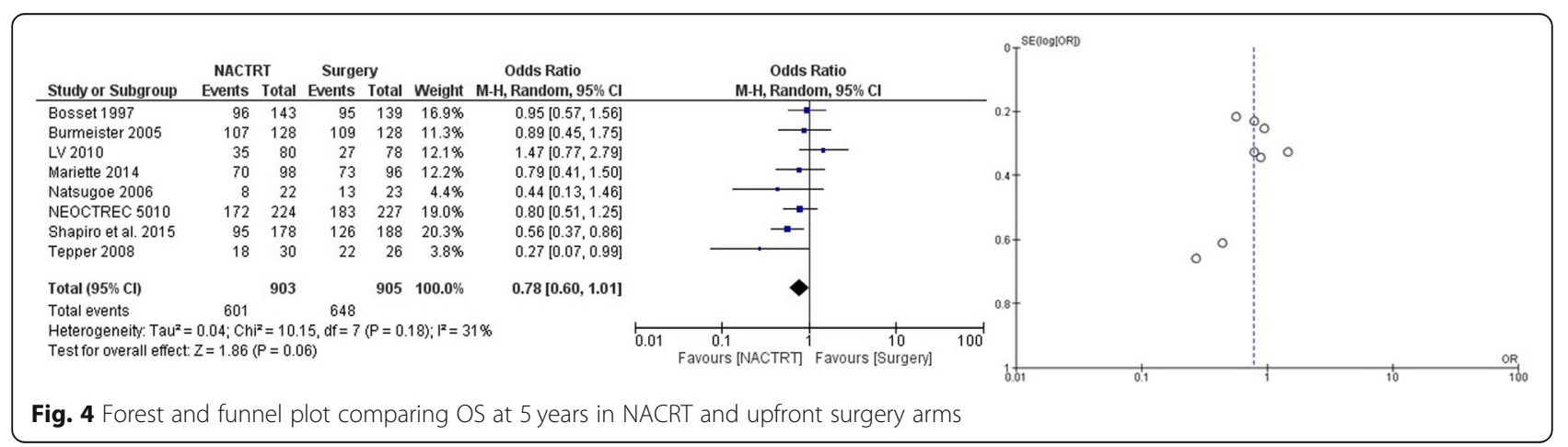




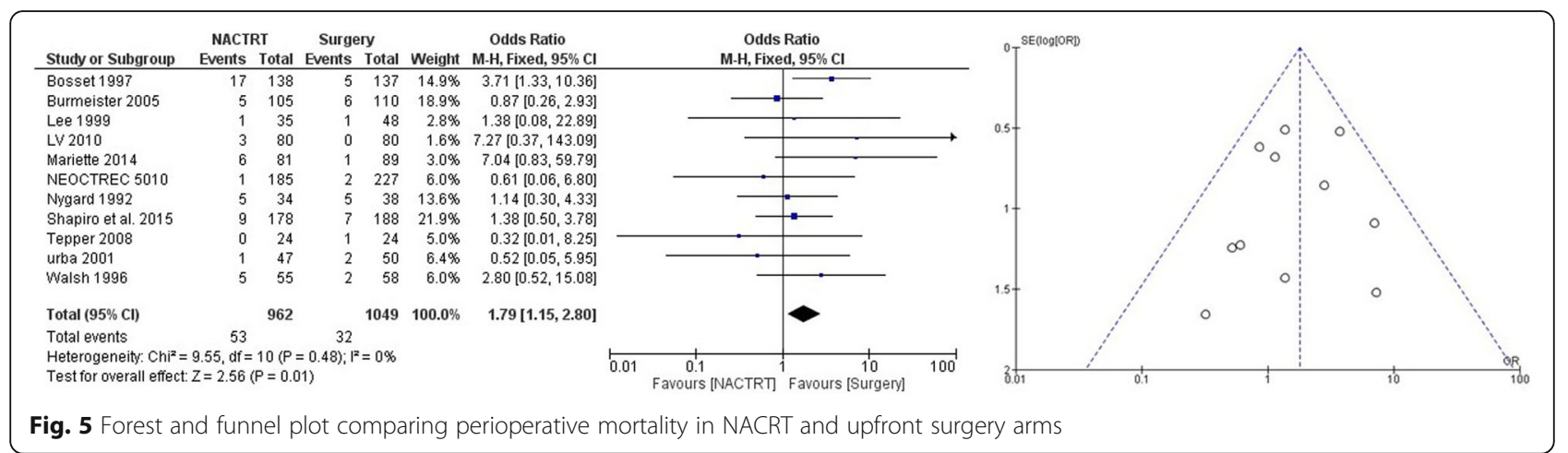

0.73-97, $p=0.016)$ and disease-specific death risk hazard ratio $(0.8495 \% \mathrm{CI} 0.72-0.97, p=.02)$. On multivariate analysis in an epidemiological study by Nassri et al. [42], it was shown that the only significant factor which benefits survival is esophagectomy, i.e., the surgery itself. They reported that $16 \%$ of patients on neoadjuvant treatment had disease progression, and only $41 \%$ underwent definitive surgery. However, the resectability rates in other studies have been quoted to be higher. On the contrary, there is retrospective data [43] suggesting that NACRT does not increase any postoperative complications with a trend towards survival benefit. A phase II randomized trial by Mao et al. (NCT01463501) which is prospectively studying the difference between neoadjuvant and adjuvant paclitaxel and carboplatin-based chemoradiation in terms of quality of life and adverse events as a measure of safety and tolerability is underway and its results are long-awaited. However, the CROSS trial by Van Hagen et al. [44] showed $4 \%$ mortality in each of the NACRT and upfront surgery arms.

NACT followed by surgery has been a popular treatment strategy practiced widely. However, this metaanalysis did not find a significant advantage of NACT in terms of OS, DFS, locoregional/systemic failures, or perioperative mortality. This is in contrast to the previous two meta-analyses by Gebski et al. [32] and Sjoquist et al. [31] which demonstrated an absolute survival benefit of $7 \%$ and 5.1\%, respectively, at 2 years, with NACT. Chan et al. [33] also showed a trend towards survival benefit with NACT, but this did not reach statistical significance. The superior results attributed to "NACT" in these studies were probably due to the benefit conferred by perioperative chemotherapy. Former meta-analyses included trials [45-47], which administered perioperative chemotherapy (preoperative and postoperative chemotherapy), thus explaining the survival benefit seen. These "peri-operative" chemotherapy studies were excluded from our analysis, and hence, our study reports the role of chemotherapy in a purely neoadjuvant sense, finding no benefit whatsoever.

NART followed by surgery made a significant impact on a 3 -year OS, reducing the risk by $42 \%(\mathrm{OR}=0.58 \mathrm{CI}$
$0.39-0.86, p=.007)$ which continued to show a trend towards significance at 5 years. Perioperative mortality and failures were not significantly different in the two groups. This strategy has not been extensively evaluated and no trials have compared chemoradiotherapy (CTRT) with radiotherapy (RT) alone.

The two trials that studied SCRT did not show benefit in any of the variables evaluated. This strategy was also re-evaluated with modifications, i.e., induction chemotherapy (docetaxel, infusional FU, cisplatin) followed by neoadjuvant chemoradiation followed by surgery, with or without cetuximab [48]. The addition of cetuximab did improve the locoregional control but did not translate in survival benefit. With the availability of more evidence in the future, the strategy is worth watching for.

This metanalysis has its limitations. We have not separately analyzed the outcomes of adenocarcinoma and squamous cell carcinoma which are known to behave and respond differently to chemotherapy and chemoradiotherapy due to lack of clarity in reporting of outcomes for these subsets in the included trials. Also, the different chemotherapy regimens and different radiotherapy schedules and doses make the data heterogenous.

Having included all studies from 1981 to 2018, the long span of 37 years has diagnostic and therapeutic variations in the management of esophageal cancer ranging from differences in staging, chemotherapeutic agents, radiation technology, operative techniques, and critical care, making the interpretation of results even more challenging.

Additionally, we were not able to procure full texts of three trials that fulfilled eligibility criteria; hence, they were not included for the meta-analyses. Despite these shortcomings of the present meta-analysis, the results clearly indicate the benefits of neoadjuvant chemoradiation. With the availability of more data and more strategies, this too is set to change soon with induction chemotherapy followed by neoadjuvant chemoradiation followed by surgery emerging as viable and better option [49]. 


\section{Conclusions}

This metanalysis shows unequivocal superiority of NACRT followed by surgery in the treatment of resectable esophageal cancer in terms of survival, and although this should be considered standard of care, it comes at the cost of significantly increased perioperative mortality. The role of chemotherapy in a purely neoadjuvant setting is questionable and if unavoidable, should be consolidated with adjuvant chemotherapy, after definitive surgery.

In light of the above facts, these results suggest the need for further research to determine the timing of chemoradiation to obtain maximum survival benefit without postoperative morbidity or mortality.

\section{Supplementary information}

Supplementary information accompanies this paper at https://doi.org/10. 1186/s12957-020-01830-x.

Additional file1:. Forest and funnel plot comparing 3-year DFS in NACRT and upfront surgery arms.

Additional file 2:. Forest and funnel plot comparing 5-year DFS in NACRT and upfront surgery arms.

Additional file 3:. Forest and funnel plot comparing perioperative mortality in NACT and upfront surgery arms.

Additional file 4:. Forest and funnel plot comparing failures in NACT and upfront surgery arms.

Additional file 5:. Forest and funnel plot comparing 3-year DFS in NACT and upfront surgery arms.

Additional file 6:. Forest and funnel plot comparing 3-year OS in NACT and upfront surgery arms.

Additional file 7:. Forest and funnel plot comparing 5-year DFS in NACT and upfront surgery arms.

Additional file 8:. Forest and funnel plot comparing 5-year OS in NACT and upfront surgery arms.

Additional file 9:. Forest and funnel plot comparing perioperative mortality in NART and upfront surgery arms.

Additional file 10:. Forest and funnel plot comparing failures in NART and upfront surgery arms.

Additional file 11:. Forest and funnel plot 3-year OS in NART and upfront surgery arms.

Additional file 12:. Forest and funnel plot comparing 5-year OS in NART and upfront surgery arms.

Additional file 13:. Forest and funnel plot comparing 3-year OS in SCRT and upfront surgery arms.

Additional file 14:. Forest and funnel plot comparing perioperative mortality in SCRT and upfront surgery arms.

Additional file 15:. PRISMA Checklist

\section{Abbreviations}

Cl: Confidence interval; DFS: Disease-free survival; EGC: Esophago-gastric cancer; FU: Fluorouracil; NACRT: Neoadjuvant chemoradiation; NACT: Neoadjuvant chemotherapy; NART: Neoadjuvant radiation; OR: Odds ratio; OS: Overall survival; PRISMA: Preferred Reporting Items for Systematic Reviews and Meta-Analyses; SCRT: Sequential chemoradiation

\section{Author's contribution}

TK and MP designed the study. EP did the literature search and created the figures and tables. RS and NF extracted and collated the data. TK, EP, and MP analyzed, interpreted, and prepared the manuscript.

\section{Funding}

This research did not receive any specific grant from funding agencies in public, commercial, or not-for-profit sectors.

Availability of data and materials

All data generated or analyzed during this study are included in this published article [and its supplementary information files].

Ethics approval and consent to participate

Not applicable

\section{Consent for publication}

Not applicable

\section{Competing interests}

The authors declare that they have no competing interests.

\section{Author details}

${ }^{1}$ Department of Surgical Oncology, Banaras Hindu University, Varanasi 221005, India. ${ }^{2}$ Department of Surgical Oncology, Tata Memorial Centre, Mumbai 400012, India. ${ }^{3}$ Department of Surgical Oncology, Asian Institute of Oncology, Mumbai 400022, India.

Received: 17 January 2020 Accepted: 27 February 2020

Published online: 21 March 2020

\section{References}

1. Tustumi F, Kimura CMS, Takeda FR, et al. Prognostic factors and survival analysis in esophageal carcinoma. Arq Bras Cir Dig. 2016;29(3):138-41. https://doi.org/10.1590/0102-6720201600030003.

2. Allum WH, Stenning SP, Bancewicz J, Clark PI, Langley RE. Long-term results of a randomized trial of surgery with or without preoperative chemotherapy in esophageal cancer. J Clin Oncol. 2009;27(30):5062-7. https://doi.org/10.1200/JCO.2009.22.2083.

3. Ancona E, Ruol A, Santi S, et al. Only pathologic complete response to neoadjuvant chemotherapy improves significantly the long term survival of patients with resectable esophageal squamous cell carcinoma: final report of a randomized, controlled trial of preoperative chemotherapy versus . Cancer. 2001;91(11):2165-2174. doi:https://doi.org/10.1002/10970142(20010601)91:11 < 2165:.:AID-CNCR1245 > 3.0.CO;2-H.

4. Kelsen DP, Ginsberg R, Pajak TF, et al. Chemotherapy followed by surgery compared with surgery alone for localized esophageal cancer. N Engl J Med. 1998:339(27):1979-84. https://doi.org/10.1056/NEJM199812313392704.

5. Law S, Fok M, Chow S, et al. Preoperative chemotherapy versus surgical therapy alone for squamous cell.

6. Lee $\mathrm{J}$, Park SI, Kim SB, et al. A single institutional phase III trial of preoperative chemotherapy with hyperfractionation radiotherapy plus surgery versus surgery alone for resectable esophageal squamous cell carcinoma. Ann Oncol. 2004;15(6):947-54. https://doi.org/10.1093/annonc/ mdh219.

7. Maipang T, Vasinanukorn P, Petpichetchian C, et al. Induction chemotherapy in the treatment of patients with carcinoma of the esophagus. J Surg Oncol. 1994;56(3):191-7. https://doi.org/10.1002/jso.2930560314.

8. Mariette C, Dahan L, Mornex F, et al. Surgery alone versus chemoradiotherapy followed by surgery for stage I and II esophageal cancer: final analysis of randomized controlled phase III trial FFCD 9901. J Clin Oncol. 2014;32(23):2416-22. https://doi.org/10.1200/JCO.2013.53.6532.

9. Girling DJ, Bancewicz J, Clark PI, et al. Surgical resection with or without preoperative chemotherapy in oesophageal cancer: a randomised controlled trial. Lancet. 2002;359(9319):1727-33. https://doi.org/10.1016/ S0140-6736(02)08651-8.

10. Natsugoe S, Okumura H, Matsumoto M, et al. Randomized controlled study on preoperative chemoradiotherapy followed by surgery versus surgery alone for esophageal squamous cell cancer in a single institution. Dis Esophagus. 2006;19(6):468-72. https://doi.org/10.1111/j.1442-2050.2006. 00615.x. 
11. Yang H, Liu H, Chen $Y$, et al. Neoadjuvant chemoradiotherapy followed by surgery versus surgery alone for locally advanced squamous cell carcinoma of the esophagus (NEOCRTEC5010): a phase III multicenter, randomized, open-label clinical trial. J Clin Oncol. 2018;36(27):2796-803. https://doi.org/ 10.1200/JCO.2018.79.1483.

12. Nygaard $\mathrm{K}$, Hagen $\mathrm{S}$, Hansen $\mathrm{HS}$, et al. Pre-operative radiotherapy prolongs survival in operable esophageal carcinoma: a randomized, multicenter study of pre-operative radiotherapy and chemotherapy. The second scandinavian trial in esophageal cancer. World J Surg. 1992;16(6):1104-9. https://doi.org/ 10.1007/BF02067069.

13. Prise $\mathrm{E}$ Le, Etienne $\mathrm{PL}$, Meunier $\mathrm{B}$, et al. A randomized study of chemotherapy, radiation therapy, and surgery versus surgery for localized squamous cell carcinoma of the esophagus. Cancer. 1994;73(7):1779-1784. doi:https://doi.org/10.1002/1097-0142(19940401)73:7 < 1779::AIDCNCR2820730702 > 3.0.CO;2-T.

14. Ando N, lizuka $\mathrm{T}$, Ide $\mathrm{H}$, et al. Surgery plus chemotherapy compared with surgery alone for localized squamous cell carcinoma of the thoracic esophagus: a Japan Clinical Oncology Group Study - JCOG9204. J Clin Oncol. 2003;21(24):4592-6. https://doi.org/10.1200/JCO.2003.12.095.

15. Schlag PM. Randomized trial of preoperative chemotherapy for squamous cell cancer of the esophagus. Arch Surg. 1992;127(12):1446-50. https://doi. org/10.1001/archsurg.1992.01420120080015.

16. Shapiro J, van Lanschot JJB, Hulshof MCCM, et al. Neoadjuvant chemoradiotherapy plus surgery versus surgery alone for oesophageal or junctional cancer (CROSS): Long-term results of a randomised controlled trial. Lancet Oncol. 2015;16(9):1090-8. https://doi.org/10.1016/S14702045(15)00040-6.

17. Tepper J, Krasna MJ, Niedzwiecki D, et al. Alone for esophageal cancer : CALGB 9781. J Clin Oncol. 2008;26(7):1086-92. https://doi.org/10.1200/JCO. 2007.12.9593.Phase.

18. Urba SG, Orringer MB, Turrisi A, lannettoni M, Forastiere A, Strawderman M Randomized trial of preoperative chemoradiation versus surgery alone inpatients with locoregional esophageal carcinoma. J Clin Oncol. 2001;19(2): 305-13. https://doi.org/10.1200/JCO.2001.19.2.305.

19. Walsh TN, Noonan N, Hollywood D, Kelly A, Keeling N, Hennessy TPJ. A comparison of multimodal therapy and surgery for esophageal adenocarcinoma. N Engl J Med. 1996;335(7):462-7. https://doi.org/10.1056/ NEJM199608153350702

20. Mei W, Xian-Zhi G, Weibo Y, Guojun H, Liangjun W, Da-Wei Z. Randomized clinical trial on the combination of preoperative irradiation and surgery in the treatment of esophageal carcinoma: Report on 206 patients. Int J Radiat Oncol Biol Phys. 1989;16(2):325-7. https://doi.org/10.1016/0360-3016(89)90323-4.

21. Arnott SJ, Duncan W, Kerr GR, et al. Low dose preoperative radiotherapy for carcinoma of the oesophagus: results of a randomized clinical trial. Radiother Oncol. 1992;24(2):108-13. https://doi.org/10.1016/01678140(92)90287-5.

22. Baba N. Shimada, et al. Prospective evaluation of preoperative chemotherapy in resectable squamous cell carcinoma of the thoracic esophagus. Dis Esophagus. 2000;13(2):136-41. https://doi.org/10.1046/j.14422050.2000.00101.x

23. Boonstra JJ, Kok TC, Wijnhoven BPL, et al. Chemotherapy followed by surgery versus surgery alone in patients with resectable oesophageal squamous cell carcinoma: long-term results of a randomized controlled trial. BMC Cancer. 2011;11. https://doi.org/10.1186/1471-2407-11-181.

24. Bosset JF, Gignoux M, Triboulet JP, et al. Chemoradiotherapy followed by surgery compared with surgery alone in squamous-cell cancer of the esophagus. N Engl J Med. 1997. https://doi.org/10.1056/ NEJM199707173370304.

25. Burmeister B, Smithers M, Gebski V, et al. Surgery alone versus chemoradiotherapy followed by surgery for resectable cancer of the oesophagus: a randomised controlled phase III trial. Lancet Oncol. 2005;6(9): 659-68. https://doi.org/10.1016/S1470-2045(05)70288-6.

26. Cao XF, He XT, Ji L, Xiao J, LV J. Effects of neoadjuvant radiochemotherapy on pathological staging and prognosis for locally advanced esophageal squamous cell carcinoma. Dis Esophagus. 2009;22(6):477-81. https://doi.org/ 10.1111/j.1442-2050.2008.00910.x.

27. Gignoux M, Roussel A, Paillot B, et al. The value of preoperative radiotherapy in esophageal cancer: results of a study of the E.O.R.T.C. World J Surg. 1987;11(4):426-32. https://doi.org/10.1007/BF01655805.

28. Stahl M, Walz MK, Stuschke M, et al. Phase III comparison of preoperative chemotherapy compared with chemoradiotherapy in patients with locally advanced adenocarcinoma of the esophagogastric junction. J Clin Oncol. 2009. https://doi.org/10.1200/JCO.2008.17.0506.

29. Burmeister $\mathrm{BH}$, Thomas JM, Burmeister EA, et al. Is concurrent radiation therapy required in patients receiving preoperative chemotherapy for adenocarcinoma of the oesophagus? A randomised phase II trial. Eur J Cancer. 2011. https:/doi. org/10.1016/j.ejca.2010.09.009.

30. Klevebro F, von Döbeln GA, Wang $N$, et al. A randomized clinical trial of neoadjuvant chemotherapy versus neoadjuvant chemoradiotherapy for cancer of the oesophagus or gastro-oesophageal junction. Ann Oncol. 2016; 27(4):660-7. https://doi.org/10.1093/annonc/mdw010.

31. Sjoquist KM, Burmeister BH, Smithers BM, et al. Survival after neoadjuvant chemotherapy or chemoradiotherapy for resectable oesophageal carcinoma: an updated meta-analysis. Lancet Oncol. 2011;12(7):681-92. https://doi.org/10.1016/S1470-2045(11)70142-5.

32. Gebski V, Burmeister B, Smithers BM, Foo K, Zalcberg J, Simes J. Survival benefits from neoadjuvant chemoradiotherapy or chemotherapy in oesophageal carcinoma: a meta-analysis. Lancet Oncol. 2007:8(3):226-34. https://doi.org/10.1016/\$1470-2045(07)70039-6.

33. Chan KKW, Saluja R, Delos Santos K, et al. Neoadjuvant treatments for locally advanced, resectable esophageal cancer: a network meta-analysis. Int J Cancer. 2018;143(2):430-7. https://doi.org/10.1002/ijc.31312.

34. LV J, Cao XF, Zhu B, Ji L, Tao L, Wang DD. Long-term efficacy of perioperative chemoradiotherapy on esophageal squamous cell carcinoma. World J Gastroenterol. 2010. https://doi.org/10.3748/wjg.v16.i13.1649.

35. Launois B, Delarue D, Campion JP, Kerbaol M. Preoperative radiotherapy for carcinoma of the esophagus. Surg Gynecol Obstet. 1981;153(5):690-2.

36. Jadad AR, Moore RA, Carroll D, et al. Assessing the quality of reports of randomized clinical trials: is blinding necessary? Control Clin Trials. 1996. https://doi.org/10.1016/0197-2456(95)00134-4.

37. Song F, Khan KS, Dinnes J, Sutton AJ. Asymmetric funnel plots and publication bias in meta-analyses of diagnostic accuracy. Int J Epidemiol. 2002. https://doi.org/10.1093/ije/31.1.88

38. Ahn $\mathrm{E}, \mathrm{Kang} \mathrm{H}$. Introduction to systematic review and meta-analysis: a health care perspective. Korean J Anesthesiol. 2018;71(2):1-38. file:///Files/80/ 80584189-B2E3-42FF-91B6-27BA3C2BC1A5.pdf.

39. Liberati A, Altman DG, Tetzlaff J, et al. The PRISMA statement for reporting systematic reviews and meta-analyses of studies that evaluate health care interventions: explanation and elaboration. J Clin Epidemiol. 2009. https:// doi.org/10.1016/j.jclinepi.2009.06.006.

40. Malthaner R, Yu E, Sanatani MS, et al. The quality of life in neoadjuvant versus adjuvant therapy of esophageal cancer treatment trial (QUINTETT). J Clin Oncol. 2019. https://doi.org/10.1200/jco.2019.37.15_suppl.4052.

41. Miccio JA, Oladeru OT, Yang J, et al. Neoadjuvant vs. Adjuvant treatment of Siewert type II gastroesophageal junction cancer: an analysis of data from the surveillance, epidemiology, and end results (SEER) registry. J Gastrointest Oncol. 2016. https://doi.org/10.21037/jgo.2015.10.06.

42. Nassri A, Zhu H, Muftah M, Ramzan Z. Epidemiology and survival of esophageal cancer patients in an american cohort. Cureus. 2018;10(4):1-18. https://doi.org/10.7759/cureus.2507.

43. Chen $Y$, Hao D, Wu X, et al. Neoadjuvant versus adjuvant chemoradiation for stage II-III esophageal squamous cell carcinoma: a single institution experience. Dis Esophagus. 2017. https://doi.org/10.1093/dote/dox016.

44. Van Hagen P, Hulshof MCCM, Van Lanschot JJB, et al. Preoperative chemoradiotherapy for esophageal or junctional cancer. N Engl J Med. 2012. https://doi.org/10.1056/NEJMoa1112088.

45. Cunningham D, Allum WH, Stenning SP, et al. Perioperative chemotherapy versus surgery alone for resectable gastroesophageal cancer. N Engl J Med. 2006. https://doi.org/10.1056/NEJMoa055531.

46. Roth JA, Pass HI, Flanagan MM, Graeber GM, Rosenberg JC, Steinberg S. Randomized clinical trial of preoperative and postoperative adjuvant chemotherapy with cisplatin, vindesine, and bleomycin for carcinoma of the esophagus. J Thorac Cardiovasc Surg. 1988.

47. Ychou M, Boige $V$, Pignon JP, et al. Perioperative chemotherapy compared with surgery alone for resectable gastroesophageal adenocarcinoma: an FNCLCC and FFCD multicenter phase III trial. J Clin Oncol. 2011. https://doi. org/10.1200/JCO.2010.33.0597.

48. Ruhstaller T, Thuss-Patience P, Hayoz S, et al. Neoadjuvant chemotherapy followed by chemoradiation and surgery with and without cetuximab in patients with resectable esophageal cancer: a randomized, open-label, phase III trial (SAKK 75/08). Ann Oncol. 2018;29(6):1386-93. https://doi.org/ 10.1093/annonc/mdy105. 
49. Ruhstaller T, Widmer L, Schuller JC, et al. Multicenter phase II trial of preoperative induction chemotherapy followed by chemoradiation with docetaxel and cisplatin for locally advanced esophageal carcinoma (SAKK 75/02). Ann Oncol. 2009. https://doi.org/10.1093/annonc/mdp045.

\section{Publisher's Note}

Springer Nature remains neutral with regard to jurisdictional claims in published maps and institutional affiliations.

Ready to submit your research? Choose BMC and benefit from:

- fast, convenient online submission

- thorough peer review by experienced researchers in your field

- rapid publication on acceptance

- support for research data, including large and complex data types

- gold Open Access which fosters wider collaboration and increased citations

- maximum visibility for your research: over $100 \mathrm{M}$ website views per year

At $B M C$, research is always in progress.

Learn more biomedcentral.com/submissions 